\title{
Sejarah Perkembangan Pemikiran Gerakan Salafiyah
}

\author{
Suhilman \\ Universitas Islam Negeri (UIN) Syarif Hidayatullab Jakarta \\ e-mail: suhilman@gmail.com
}

\begin{abstract}
ABSTRAK. Salafiyah is reform movement focusing on the matters of akidah and Islamic puritanism. The Islamic teaching should not be treated as a doctrin (das sein) in the society but it should be actualized as stipulated by alQur'an and Hadis (das sollen)..
\end{abstract}

Kata kunci: Gerakan Salafiyah, Ahmad ibn Hanbal, Ibn Taymiyah, Jamaluddin al-Afghani, dan Muhammad Abduh.

\section{PENDAHULUAN}

Setelah Perkembangan dakwah Islam meluas sampai ke luar semenanjung Arab, kaum Muslim menjalin hubungan langsung dengan budaya, agama, dan kecenderungan filsafat yang berbeda, seperti Yahudi, Kristen, dan Zoroaster. Kaum Muslim dihadapkan dengan situasi dan tantangan intelektual baru yang harus ditanggapi dengan respons yang mencerminkan keimanan Islam. Di samping Qur'an, kaum Muslim juga menggunakan pemikiran rasional untuk menghadirkan serta menjelaskan konsep dan doktrin Islam, seperti persoalan eksistensi Allah, sifat ketuhanan (ilabiyah), dan sifat Qur'an.

Persoalan tersebut dimulai sejak konflik kekerasan yang terjadi di kalangan kaum Muslim tentang pergantian kepemimpinan (khilafah) setelah wafatnya Khalifah Usman ibn Affan pada 35 $\mathrm{H} / 656 \mathrm{M}$ juga membuka banyak kontroversi tentang topik-topik lain seperti iman, status orang berdosa, sifat tindakan manusia, kebebasan dan tekad, serta keimanan. Oleh karena itu, disiplin dan arus intelektual baru bermunculan dalam perkembangan sejarah Islam. Para penganjurnya menjawab masalah-masalah tersebut dan memakai penafsiran Qur'an yang subjektif, menggunakan analogi, filsafat, dan ada juga yang menempatkan pemikiran rasional di atas wahyu.

Keragaman opini dan debat sengit yang terjadi dalam perkembangan sejarah Islam, menimbulkan kecenderungan intelektual lain yang menganjurkan kaum Muslim kembali kepada Islam yang murni dan sederhana, serta pemahaman doktrin berdasarkan Qur'an, dan Hadis, yang kemudian membentuk suatu paham yang dikenal dengan nama Salafiyah.

Sejarah Perkembangan Gerakan Salafiyah

Istilah Salafiyah berasal dari akar kata bahasa Arab, salafa-yaslufu-salaf, berarti mendahului, nenek moyang, leluhur, dan mazhab salaf. ${ }^{1} \quad$ Istilah ini muncul karena adanya sabda nabi Muhammad saw: sebaik-baik masa (qurun) adalah masaku, kemudian yang di belakangnya, kemudian yang di belakangnya lagi. ${ }^{2}$ Sabda nabi ini menjadi pedoman bagi orang-orang yang akan diteladani (generasi salaf). Menurut Ensiklopedi Dunia Islam Modern, generasi salaf terdiri atas tiga generasi Muslim pertama. Masa itu membentang tiga abad, abad pertama para sahabat nabi Muhammad saw (sahabah), yang berakhir dengan Anas ibn Malik (w. 91 H/710 M atau 93 H/712 M); selanjutnya pengikut mereka (tabi'in) $(180 \mathrm{H} / 796 \mathrm{M})$; dan selanjutnya pengikut dari pengikut mereka (tabi' al-tabi'in) (241 H/855 M). Ahmad ibn Hanbal (164-241 H/780-955 M) dianggap sebagai orang terakhir dari generasi salaf. ${ }^{3}$ Generasi ini dikenal kaum Muslim selanjutnya karena 
persahabatan mereka dengan nabi Muhammad saw dan kedekatan mereka dengan masa hidup nabi. Pemahaman dan praktik Islam mereka yang murni, serta sumbangan mereka bagi Islam kemudian digunakan aliran salaf sebagai dasar ajaran mereka yang bertujuan untuk mengembalikan ajaran Islam seperti yang dilakukan generasi salaf, maka gerakan ini dikenal dengan nama gerakan Salafiyah.

Usaha menghidupkan jejak generasi salaf mulai terjadi sejak abad ke-4 H/ ke-9 M, di mana pada saat itu kemajuan berpikir sangat pesatnya, dan juga munculnya aliran-aliran paham baru di kalangan umat Islam, baik dipengaruhi atau tidak oleh ajaran di luar Islam. ${ }^{4}$ Pada abad ini Ahmad ibn Hanbal, pendiri mazhab keempat sunni adalah pelopornya, ${ }^{5}$ ia dikenal dengan perjuangannya melawan doktrin Mu'tazilah tentang penciptaan Qur'an, seperti tersebut dalam dialognya dengan Is-hak ibn Ibrahim, gubernur Irak, sebagai berikut:

Ishak : apa pendapatmu tentang Qur'an?

Ibn Hanbal : sabda Tuhan

Ishak : apakah ia diciptakan?

Ibn Hanbal : sabda Tuhan, saya tidak dapat mengatakan lebih dari itu

Ishak : apa arti ayat : Maha Mendengar (sama) dan Maha Melihat (basar) (Ishak ingin menguji Ibn Hanbal tentang paham antropomorphisme)

Ibn Hanbal : Tuhan mensifatkan diri-Nya dengan kata-kata itu

Ishak : apa artinya?

Ibn Hanbal : tidak tahu, Tuhan adalah sebagaimana Tuhan mensifati diri-Nya. ${ }^{6}$

Sikap Ibn Hanbal yang dengan keberanian dan tak takut mati mempertahankan keyakinannya tersebut, membuat Ibn Hanbal mempunyai banyak pengikut di kalangan umat Islam yang tak sepaham dengan Mu'tazilah. ${ }^{7}$ Paham ini selanjutnya dikenal dengan Salafiyah klasik.

Pada abad ke-7 H/ ke-13 M, Ibn Taimiyah (661-728 H/1263-1328 M) dengan kegigihan dan keberanian yang luar biasa melanjutkan paham salafiyah ini. Mula-mula dalam pengajianpengajian, dan kemudian dalam tulisan yang tersebar luas dan menggegerkan ulama-ulama dalam mazhab lain. ${ }^{8}$

Ibn Taimiyah mendesak kaum Muslim dengan gencar untuk kembali kepada ajaran yang utama, Qur'an dan Hadis nabi Muhammad saw. Supaya ajaran Islam tidak dipertahankan sebagaimana adanya (das sein) di dalam masyarakat. Akan tetapi harus diwujudkan sebagaimana seharusnya (das sollen) seperti yang dikehendaki oleh pembawanya, nabi Muhammad saw. ${ }^{9}$ Itu semua telah dilakukan oleh generasi salaf.

Para ulama dalam memahami ajaran Islam, menurut Ibn Taimiyah, digolongkan menjadi empat kelompok. Pertama para filosof, yaitu kelompok yang mengatakan bahwa Qur'an itu dapat ditempuh dengan jalan menggunakan pengantar yang memuaskan akal manusia. Kelompok ini menyebut dirinya sebagai ahli keterangan dan ahli keyakinan. Kedua Mutakallimun, yaitu kelompok Mu'tazilah. Kelompok ini mendahulukan akal daripada ayat Qur'an. Mereka menggunakan dua sumber, Qur'an dan akal, hanya saja sumber akal lebih utama dibandingkan Qur'an; dan menggunakan takwil Qur'an sesuai dengan akal. Namun hal tersebut menurut Ibn Taimiyah tidak sampai keluar dari akidah Islam. Ketiga kelompok yang melihat apa yang ada dalam Qur'an sebagai akidah, lalu beriman kepadanya. Kelompok ini menggunakan Qur'an bukan karena Qur'an itu mengandung dalil-dalil yang pasti dan menunjukkan kepada kebenaran akal, tetapi karena Qur'an mengandung ayat-ayat yang bersifat berita yang wajib diimani tanpa menggunakan kandungan ayat sebagai pengantar konklusi akal. Al-Maturidiyah termasuk dalam kelompok ini, karena kelompok ini menggunakan akal hanya untuk menjelaskan aqidah Qur'an. Keempat, kelompok yang beriman kepada Qur'an dan dalil-dalilnya, tetapi tetap menggunakan dalil-dalil akal. Kelompok ini adalah Asy'ariyah. ${ }^{10}$

Namun, Ibn Timiyah menetapkan bahwa paham Salafiyah tidak termasuk dalam keempat kelompok tersebut, karena paham Salafiyah mempunyai metode tersendiri, yaitu menggunakan 
sumber utama Qur'an dan Hadis nabi Muhammadsaw, selain itu tidak menggunakan akal. Akal menurut paham Salafiyah adalah menyesatkan dan bid'ah. ${ }^{11}$

Kaum Salaf menurut Ibn Taimiyah adalah mereka yang berpendapat bahwa tidak ada jalan untuk mengetahui aqidah, hukum, dan apa yang ada hubungan dengan keduanya, kecuali dengan menggunakan Qur'an dan Hadis. Kaum Salaf menerima semua keterangan yang ada dalam Qur'an dan Hadis. Menolak berarti melepas tali agama. Akal tidak mempunyai kekuasaan untuk mentakwilkan, menafsirkan, atau menghukumi Qur'an. Akal hanya mampu membenarkan, mentaati, dan menerangkan pendekatan antara dalil akal (kontekstual), dengan dalil Qur'an dan Hadis (tekstual) dengan tidak ada perbedaan antara dalil akal dengan dalil Qur'an dan Hadis. Akal berkedudukan sebagai saksi bukan hakim, sebagai penetap dan penguat bukan penentang, sebagai penjelas dari dalil yang terkandung dalam Qur'an. ${ }^{12}$ Kaum Salaf selalu menjadikan akal berada di belakang Qur'an dan Hadis.

Pada abad ke-12 H/18 M, muncul gerakan-gerakan reformasi untuk menangani kehancuran moral dan sosial umat Islam. Gerakan Wahabiyah adalah yang terpenting. Pendirinya, Muhammad Ibn Abdul Wahab (1703-1792 M). Beliau menggunakan ajaran Ibn Hanbal dan Ibn Taimiyah untuk memurnikan semenanjung Arab dari praktik non-Islam dan membangun negara Islam yang meneladani negara yang didirikan nabi Muhammad saw. Wahabiyah mempengaruhi gerakan reformasi lainnya, seperti Sanusiyah dan Mahdiyah yang memiliki kecenderungan sufi. ${ }^{13}$

Gerakan yang sama dengan Wahabiyah bermunculan di luar dunia Arab. Gerakan Usuman dan Fodio (1754-1817 M) di Nigeria. Gerakan Ahmad Sirhindi (1564-1624 M), Syah Wali Allah (1702-1752 M), dan Sayyid Ahmad Barelwi (1786-1831 M) di anak benua India. Gerakan tersebut menganjurkan pemurnian agama, reformasi moral, dan sosial, serta persatuan Muslim. Namun, gerakan tersebut tetap menafsirkan agama secara harfiah dan terikat pada masa lalu; berjuang bukan untuk membangun model yang bisa hidup pada masa depan, melainkan menciptakan kembali model awal seperti masa nabi dan para sahabatnya. ${ }^{14}$

Meskipun demikian, gerakan tersebut meninggalkan warisan yang mengilhami gerakan reformasi pada abad selanjutnya, abad ke-19 dan 20 M, yang dikenal dengan gerakan Salafiyah Modern.

Gerakan Salafiyah modern didirikan Jamaluddin al-Afghani (1839-1897 M) dan Muhammad Abduh (1849-1905 M). Tujuan utama gerakan ini adalah menyingkirkan umat Islam dari mentalitas taqlid (imitasi buta) dan jumud (stagnasi), mengembalikan Islam pada bentuk murninya, dan mereformasi kondisi moral, budaya, dan politik kaum Muslim. ${ }^{15}$

Untuk melawan warisan stagnasi, kehancuran moral, sosial, politik, dan dominasi asing, gerakan Salafiyah modern yang diserukan al-Afghani dan Abduh, adalah menghidupkan kembali Islam seperti generasi salaf, menjembatani perbedaan antara Islam historis dan modernitas, dan memulihkan solidaritas dan kekuatan kaum Muslim. ${ }^{16}$

Selanjutnya gerakan Salafiyah modern memusatkan perhatiannya pada beberapa persoalan yang membentuk fondasi ideologi Salafiyah modern. Di antaranya adalah penyebab kelemahan kaum Muslim, reinterpretasi Islam, serta reformasi komprehensif dan institusional. ${ }^{17}$

Gerakan Salafiyah modern berpendapat bahwa penyebab yang membawa kepada kemunduran kaum Muslim adalah sikap jumud yang terdapat pada diri umat Islam. Jumud mengandung arti keadaan membeku, statis, dan tak ada perubahan. Oleh karena sikap jumud, umat Islam tidak menghendaki adanya perubahan, sebaliknya umat Islam hanya menerima tradisi yang berkembang pada saat itu. ${ }^{18}$ Sikap tersebut menyebabkan umat Islam melupakan ajaran Islam yang sebenarnya, dan berada dalam fanatik buta, serta mewujudkan penyelewenganpenyelewengan dalam ajaran Islam.

Untuk mengubah keadaan tersebut, gerakan Salafiyah modern berusaha mengembalikan umat Islam kepada ajaran Islam asli, yaitu ajaran-ajaran Islam yang terdapat dalam generasi salaf. ${ }^{19}$ Selanjutnya disesuaikan dengan keadaan dan situasi yang ada pada saat itu. Gerakan Salafiyah modern melakukan penyesuaian mengikuti cara Ibn Taimiyah, membedakan antara yang tidak berubah dan yang berubah dalam agama Islam. Hal yang tidak berubah berkenaan dengan 
masalah keyakinan dan ibadah ritual (ibadat), yang telah dirumuskan dalam Qur'an dan Hadis. Menambah sesuatu yang tidak terdapat dalam Qur'an dan Hadis dianggap sebagai bid'ah yang tidak dapat diterima. Oleh karena itu, Salafiyah modern melancarkan kampanye sengit melawan tarekat sufi, menuduh mereka memperkenalkan bid'ah, mempraktikkan ritual asing, dan menyebarkan sikap pasrah, menyerah dan tahayul.

Bagian agama yang berubah adalah mu'amalat, mencakup transaksi manusia dan hukum yang mengatur hubungan sosial. Hal ini dianggap sebagai ijtihad yang harus dilaksanakan sejalan dengan kebutuhan modernitas dan kemajuan ilmu pengetahuan. ${ }^{20}$ Tetapi yang dimaksud ijtihad di sini adalah tidak setiap orang boleh mengadakan ijtihad, hanya orang-orang yang memenuhi syarat yang diperlukan yang boleh berijtihad. Yang tidak memenuhi syarat, harus mengikuti pendapat mujtahid yang merujuk langsung pada al-Qur'an dan Hadis, dan dilarang meniru buta kepada ulama-ulama tradisional pada saat itu. ${ }^{21}$ Dengan menekankan kembali keyakinan umat Islam pada kemampuan berpikir untuk merujuk langsung sumber asli, dengan sendirinya akan membebaskan umat Islam dari taklid buta pada otoritas tradisi saat itu.

Kelemahan umat Islam lainnya adalah menghadapi ancaman budaya kolonialisme Barat. Salafiyah modern berupaya menegaskan validitas Islam pada masa modern dan membuktikan kesesuaiannya dengan akal dan ilmu pengetahuan. Salafiyah modern memandangnya sebagai pesan menyeluruh yang mencakup segala aspek kehidupan dan sebagai kekuatan pendorong bagi kemajuan . Bagi Salafiyah, Islam memberikan fondasi kemajuan kepada kaum Muslim. Islam memuliakan dan menegaskan kedaulatan manusia di bumi, memberkati kaum Muslim dengan tauhid, dan mendukung pencarian pengetahuan dan kemajuan. Oleh karena itu, para pemikir Salafiyah modern mencoba mengembalikan kebanggaan kaum Muslim akan agama mereka, memuluskan jalan untuk reinterpretasi Islam sesuai dengan modernitas, dan melegitimasi pengambilan pengetahuan sebagai prestasi ilmiah. ${ }^{22}$

Salafiyah mengidentifikasi akar masalah tidak terletak dalam ajaran Islam, tetapi dalam infiltrasi konsep dan praktik asing, disintegrasi umat Islam, dan praktik despotisme politik. Distorsi keyakinan Islam adalah dasar penyebaran sikap kepasrahan, kepasifan, dan ketundukan di kalangan Muslim, yang berujung pada stagnasi dan taklid buta kepada para ulama tradisionalis. Masalah ini menghambat kemajuan Muslim dan mencegah mereka mengejar kekuasaan dan kemerdekaan. Dengan demikian, diberlakukannya ijtihad merupakan kekuatan yang memelihara vitalitas Islam dan mengaitkannya dengan kehidupan nyata. ${ }^{23}$

Dalam pernyataan tersebut, Salafiyah berupaya menjembatani jurang di masyarakat dengan memperkenalkan reformasi luas pada tingkat individual dan institusional. Pendidikan adalah batu loncatan bagi rencana reformasi mereka. Salafiyah yakin bahwa reformasi tidak akan efektif kecuali nilai moral dan sosial Muslim dihidupkan kembali melalui pendidikan. Salafiyah beraspirasi untuk mendidik tipe elit baru, memadukan pendidikan Islam yang modern, guna menutup jarak antara kaum konservatif dan kaum terbaratkan. Salafiyah berupaya merestrukturisasi sistem pendidikan dan memodernisasi kurikulum lembaga pendidikan tradisional, serta mendirikan sekolah baru yang menawarkan mata pelajaran Islam maupun modern. ${ }^{24}$

Berkaitan dengan pendidikan di antaranya adalah reformasi bahasa Arab. Akibat keadaan stagnasi dan imitasi secara keseluruhan, bahasa Arab selama berabad-abad menderita kekakuan dan gaya artifisial. Reformasi bahasa bertujuan menghidupkannya kembali dan membebaskannya dari bentuk klasik supaya lebih mudah dipahami dan menyerap istilah modern. Oleh karena itu, Salafiyah di dunia Arab berharap mampu melestarikan identitas nasional mereka dan membendung penyebaran bahasa asing. ${ }^{25}$

Reformasi hukum adalah aspek penting lainnya dalam upaya untuk menghidupkan kembali Islam murni. Salafiyah menyatakan bahwa hukum harus mencerminkan semangat bangsa, nilai, dan sistem keyakinan. Hukum impor dan asing tidak akan pernah mampu menanamkan akar yang dalam, karena tidak akan pernah mendapatkan penerimaan konsepsual maupun legitimasi. Syariat Islam mengatur urusan hukum dan menganjurkan reinterpretasi atas akal, 
maqasid (tujuan), dan maslahab (kepentingan), khususnya kepentingan yang tidak diatur dalam Qur'an. Pada tingkat institusional, Salafiyah berupaya mendirikan sekolah khusus untuk hakim syariah, atau mereformasi sekolah yang sudah ada, dan mereformasi pengadilan syariah. ${ }^{26}$

Salafiyah menegaskan bahwa reformasi politik sebagai syarat esensial untuk menghidupkan kembali umat Islam, dan mengecam despotisme dan menuntut tanggung jawab pemimpin otokratis atas penyebaran sikap pasrah dan disintegrasi kaum Muslim. Salafiyah menganjurkan rencana bertahap dalam reformasi politik. Mereka yakin bahwa reformasi politik tidak akan dapat dicapai kecuali rakyat dididik tentang hak dan kewajiban sebagai bangsa (warga negara)..$^{27}$

Salafiyah berupaya merumuskan kembali konsep Islam sambil mempertimbangkan idealisme dan praktik politik modern. Salafiyah menafsir ulang konsep-konsep seperti syura (musyawarah) dan ijma' (konsensus), menyetarakannya dengan demokrassi dan sistem parlementer. Dalam praktik, Salafiyah menyerukan perwakilan yang berangsur-angsur meningkat dalam lembaga administratif dan politik. ${ }^{28}$

Kolonialisme dan ancaman penjajahan budaya memberi semangat nasionalisme yang kuat. Salafiyah berusaha mempertahankan pendirian antikolonial, dan mempromosikan kesadaran umum tentang nasionalisme Islam dan melestarikan solidaritas umat, dengan menganjurkan PanIslam dan pemulihan nukleus politik. ${ }^{29}$ Meskipun demikian, Salafiyah harus mengompromikan posisi idealisnya dalam memenuhi realitas massa, dan menerima perpecahan nasional yang menimpa dunia Muslim. Oleh karena itu, keberlanjutan pesan reformasi Salafiyah bergantung pada upaya intelektual Muslim selanjutnya.

Salafiyah telah memiliki banyak bentuk dan pengungkapan yang berbeda-beda akibat kondisi yang berubah-ubah. Namun, sepanjang fase-fasenya yang berbeda itu, pada intinya Salafiyah tetap merupakan gerakan reformasi dan pembaharuan yang berfokus pada masalah keyakinan, kemurnian Islam, dan pemulihan model Islam seperti masa generasi salaf.

\section{Metode Pemikiran Salafiyah}

Secara garis besar, Salafiyah bertopang pada tiga prinsip utama yang sekaligus merupakan metode pemikiran Salafiyah, dalam rangka mewujudkan Islam seperti pada generasi Salaf. Pertama, mengutamakan teks wahyu di atas akal. Kedua, menolak kalam (persoalan teologi). Dan ketiga, ketaatan ketat pada Qur'an, Hadis, dan konsensus (ijma').

Pengutamaan teks wahyu di atas akal, dalam hal ini, Salafiyah tidak melihat kontradiksi antara akal dan kitab suci. Namun, akal pikiran tidak mempunyai kekuasaan untuk menakwilkan, menafsirkan, atau menguraikan Qur'an, kecuali dalam batas-batas yang diizinkan oleh kata-kata (bahasa) dan dikuatkan oleh Hadis. Kekuasaan akal pikiran sesudah itu tidak lain hanya membenarkan dan tunduk kepada wahyu, kemudian mendekatkannya kepada alam pikiran. Jadi fungsi akal dalam hal ini hanya menjadi saksi pembenar dan penjelas dalil-dalil Qur'an, bukan hakim yang mengadili dan menolak dalil-dalil Qur'an. ${ }^{30}$

Salafiyah tidak mengunggulkan, menuhankan, dan tidak menganggap akal dapat berdiri sendiri, tetapi menempatkannya sesuai kedudukannya. Akal digunakan dalam batas-batas wilayahnya, seperti memikirkan alam, masalah-masalah fikih, dan menemukan ilmu-ilmu yang bersifat kebendaan yang bertujuan meningkatkan dan mengembangkan masyarakat. ${ }^{31}$

Sikap Salafiyah tersebut bukan sikap apatis, skeptis, dan pesimis, melainkan suatu kesadaran dan pengakuan akan adanya batas-batas kemampuan daya kerja akal manusia dan lingkupnya dalam bidang aqidah.

Salafiyah dalam memahami aqidah menggunakan lima prinsip dasar, yaitu tidak melakukan dan menggunakan ta'wil, tamsil, tasybih, ta'til, dan tafwid. ${ }^{32}$

Salafiyah mengimani seluruh yang ada dalam Qur'an dan Hadis, tanpa mengurangi dan menambah, tanpa mentakwil dan menyimpangkan artinya. Karena masa sahabat, tabi'in, dan para imam generasi salaf telah berakhir dalam keadaan menerima mutlak apa yang ada dalam Qur'an dan Hadis tentang dzat dan sifat-sifat Tuhan, tidak menolak satu masalahpun. 
Salafiyah meyakini bahwa nama dan sifat Tuhan bersifat tauqifizyah (apa adanya dari Allah dan Rasul-Nya), tidak boleh diisbatkan (ditetapkan) atau dinafikan (dihilangkan) kecuali dengan izin syara', yaitu mengistinbatkan nama dan sifat Tuhan sesuai dengan Qur'an dan Hadis. Nama dan sifat Tuhan yang telah ditetapkan dalam Qur'an dan Hadis tidak menyerupai makbluk. (penciptaan-Nya). Seluruh sifat-sifat kesempurnaan yang tetap bagi Tuhan yang disebutkan dalam teks Qur'an dengan jelas adalah khusus untuk menyifati Tuhan. Apabila ada nama yang ditetapkan untuk Tuhan tetapi juga ditetapkan untuk makhluk-Nya, maka persamaan tersebut hanya dalam nama dan arti umumnya, tidak dalam hakikat Tuhan, karena dzat Tuhan tidak sama dengan dzat makhluk-Nya. Oleh karena itu sifat Tuhan berbeda dengan sifat makhluk-Nya, karena Tuhan tidak dapat disamakan dengan makhluk-Nya, baikpada dzat maupun sifat-Nya. ${ }^{33}$

Qur'an telah memadukan antara isybah dan tanzih (penyerupaan dan pensucian), dalam ayat:

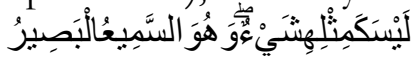

....tidak ada sesuatupun yang menyerupai Allah, sedangkan Dia Maha Mendengar lagi Maha Melihat (QS 42:11).

Tuhan Maha Mendengar lagi Maha Melihat, tidak sama dengan melihat dan mendengar makhluk-Nya. Adanya persamaan dalam sifat, tumbuh dari persamaan dalam dzat. Oleh karena dzat Tuhan berbeda sama sekali dengan dzat makhluk-Nya, maka sifat-Nya pun demikian. Dengan demikian, pemberian nama kepada Tuhan dengan Yang Kuasa tidak mengharuskan samanya kekuasaan Tuhan dengan kekuasaan makhluk-Nya,${ }^{34}$ dan seterusnya. Dalam hal tersebut, Salafiyah menolak takwil. Salafiyah menerima takwil dalam dua hal, pertama, takwil berarti tafsir dan penjelasan maknanya, baik sesuai dengan lahiriahnya maupun tidak. Dengan pengertian ini, maka makna tafsir identik dengan takwil. Seperti Imam Muhammad ibn Jarir al-Thabari dalam tafsirnya berkata: Pendapat tentang takwil ayat ini adalah sebagaimana adanya, dan para ahli takwil berikhtilaf dalam ayat ini sesuai dengan pendapat mereka. Maksud takwil menurut Salafiyah adalah tafsir. Dengan makna ini, Qur'an seluruhnya, baik mubkam maupun mutasyabih, dapat ditakwil (ditafsir). Kedua, takwil berarti maksud dari ucapan itu sendiri. Jika suatu ucapan itu perintah atau larangan, maka takwilnya adalah perbuatan orang yang diperintahkan itu sendiri terhadap perintah atau larangan tersebut, sebagaimana dituturkan Aisyah : Rasulullah saw itu dalam ruku dan sujudnya membaca:

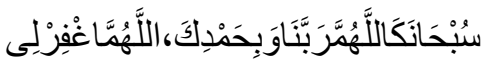

Maha suci Engkau, ya Allah Tuhan kami dan dengan segenap puji kepada-Mu ya Allah ampunilah aku.

Sebagaimana pentakwilan terhadap Qur'an, Hadis tersebut merupakan pelaksanaan perintah dari Qur'an:

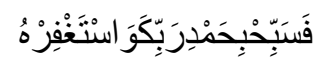

Maka bertasbihlah dengan memuji Tuhanmu dan mohonlah ampun kepada-Nya (QS alNasr : 3).

Ucapan tersebut berupa berita, takwilnya adalah yang diberitakan tersebut (berita itu sendiri). Oleh karena itu, takwil dari apa yang diberitakan Tuhan tentang diri-Nya dan tentang hari kiamat adalah hakikat dzat dan sifat-Nya yang tidak diketahui selain Tuhan. Itulah yang mutasyabih, takwil sebenarnya hanya diketahui Tuhan, tidak seorangpun yang mengetahui hakikat yang Tuhan beritakan tentang diri dan sifat-Nya tersebut. Itulahyang wajib kita serahkan kepada Tuhan untuk mengetahuinya. ${ }^{35}$ Di sini Salafiyah membatasi makna mutasyabih dan menjelaskan bahwa Qur'an itu seluruhnya jelas dan dapat ditafsirkan.

Dalam memahami masalah agama, selain aqidah, Salafiyah menggunakan ketaatan ketat pada Qur'an, Hadis, dan konsensus (ijma) para generasi Salaf. ${ }^{36}$ Al-Qur'an mencakup dakwah kepada tauhid dan menyebarkan dalil-dalil tauhid ke dalam jiwa dan pikiran. Al-Qur'an mengguggah dan mendorong manusia untuk merenung dan memikirkan dalil-dalil tersebut, di samping menjelaskan penetapan sifat-sifat Tuhan, kebenaran para rasul, perkara alam gaib, dan masalah prinsip beragama lainnya dengan dalil akal. Al-Qur'an menjawab tuduhan orang musyrik, menjelaskan syubhat dan menolak kekeliruan dalam beragama. ${ }^{37}$ 
Hadis, bagi Salafiyah merupakan sumber kedua setelah Qur'an untuk pedoman hidup, ${ }^{38}$ sedangkan ijma' merupakan putusan permusyawaratan. Dengan sendirinya karena menggunakan kemerdekaan berpikir dalam dua sumber, sering terjadi perbedaan paham satu dengan lainnya, walaupun tidak menyolok, karena Qur'an dan Hadis masih tetap dipakai untuk menuntut penetapan hukum. ${ }^{39}$ Dalam hal ini, Salafiyah menetapkan pedoman ketat dalam penggunaan ijtihad (penalaran independen), dan membatasi qiyas (penalaran analogis), namun tetap mentaati Qur'an dan Hadis. ${ }^{40}$

Dalam tafsir tentang Qur'an, Salafiyah mencoba mengaitkan kitab suci dengan kondisi masa kini. Pendekatan ini turut membangkitkan pesan Qur'an memulihkan relevansinya, dan membuatnya mudah dipahami Muslim awam. Pendekatan ini menawarkan alternatif untuk penafsiran tradisionalis harfiah. Salafiyah menyarankan jalan untuk pembaruan Islam dan pendekatan baru terhadap fikih dan etika, mengikuti jalan Ibn Taimiyah : membedakan antara yang tidak berubah dan yang berubah dalam agama. ${ }^{41}$

\section{Pandangan Salafiyah tentang Takdir}

Dalam masalah ini, Salafiyah menegaskan bahwa beriman dengan takdir baik dan buruk adalah beriman kepada kesempurnaan kekuasaan dan kehendak Tuhan. Beriman bahwa Tuhan adalah pencipta manusia dan menciptakan apa saja yang dimiliki manusia. Di samping itu manusia juga mempunyai kebebasan berbuat apa saja yang diinginkannya dengan kekuatan dan kehendak manusia itu sendiri. Tuhan pencipta segala sesuatu, Tuhan menciptakan manusia yang selalu keluh kesah apabila mengalami musibah, dan apabila mendapatkan kebaikan, akan kikir. Manusia itu pelaku perbuatan yang mempunyai pilihan, kehendak, dan kekuasaan seperti dalam Qur'an (QS al-Takwir: 28-29)

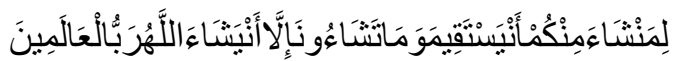

Bagi siapa di antara kamu yang mau menempuh jalan lurus, dan kamu tidak menghendaki kecuali apabila dikehendaki Allah, Tuhan semesta alam. ${ }^{42}$

Takdir meliputi khair dan syar, sedikit dan banyak, lahir dan batin, manis dan pahit, baik dan buruk, dibenci dan disenangi, awal dan akhir. Berlakunya takdir Tuhan atas manusia, dengan sendirinya tidak ada satupun manusia yang dapat lari dari masyi'ah (kehendak Tuhan), dan dapat melampaui-Nya. Bahkan kesemuanya itu akan berakhir kepada apa yang sudah Tuhan ciptakan, yaitu sesuai takdir yang telah digariskan. Manusia siap melakukan aktifitas yang telah ditakdirkan. ${ }^{43}$ Semua perbuatan yang dilakukan manusia adalah ciptaan Tuhan, namun manusia mempunyai kehendak untuk memilih perbuatan yang akan dilakukannya, baik berupa perbuatan baik maupun buruk.

Kekuasaan dan kehendak Tuhan bukanlah argumen bagi siapapun terhadap Tuhan dan kreasi-Nya...., jadi takdir adalah suatu objek keimanan, tetapi tidak bisa menjadi dasar bagi suatu argumen. Orang yang tidak percaya kepada takdir adalah seperti orang-orang majusi, tetapi mereka yang menggunakannya sebagai dasar argumen adalah seperti orang musyrik yang menentang nabi Muhammad saw dengan mengatakan bahwa seandainya Tuhan menghendaki, tentulah mereka tidak menjadi orang-orang musyrik. ${ }^{44}$

Kekuasaan Tuhan adalah universal, begitu pula kesempurnaan kekuasaan-Nya. Sedangkan manusia memiliki beban tanggungjawab atasa perbuatannya. Dalam hal ini, Salafiyah menetapkan tiga hal. Pertama, Tuhan menciptakan segala sesuatu. Tidak ada sesuatu tanpa adanya kehendak dari-Nya. Tidak ada sesuatu yang bisa menolak kehendak-Nya, karenanya dalam persoalan ini. Salafiyah sesuai dengan Jabariyah. Kedua, sesungguhnya seorang manusia itu betul-betul berbuat, yaitu memiliki keinginan dan kehendak yang sempurna yang merupakan pilihannya, dengan sendirinya manusia itu mempunyai tanggung jawab atas sesuatu yang diperbuatnya. Dalam persoalan ini Salafiyah sesuai dengan Mu'tazilah. Ketiga, sesungguhnya Tuhan memberi kemudahan bagi hamba yang berbuat baik, menyukai, dan senang perbuatan baik, tetapi Tuhan memberikan kemudahan, tidak senang, dan tidak rela terhadap perbuatan jelek, dalam hal ini Ibn Taimiyah mengikuti Mu'tazilah. ${ }^{45}$ 
Kemudian Ibn Taimiyah menggabungkan ketiga hal berbeda tersebut dengan menempatkan keadilan Tuhan dalam siksa dan pahala adalah semua perbuatan itu berasal dari Tuhan, yaitu menurut Ibn Taimiyah semua perbuatan manusia itu berasal dari dirinya karena kemampuannya, dan juga berasal dari Tuhan, karena Tuhanlah yang menciptakan kemampuan untuk berbuat itu. Tuhan adalah penyebab bagi sebala sebab, karena Tuhan adalah pencipta segala sesuatu dengan sebab-sebab yang diciptakan-Nya. Tuhan menciptakan manusia yang dengannya dia berbuat sesuatu, selanjutnya manusia itulah yang mengerjakan pekerjaannya.

Semua perbuatan manusia selalu bersandar kepada Tuhan, karena Tuhan pencipta sebab adanya perbuatan, yaitu pencipta kemampuan manusia untuk berbuat dalam dirinya. Dengan demikian pendapat Ibn Taimiyah, mendekati pendapat Mu'tazilah, namun Ibn Taimiyah berselisih pendapat dalam dua hal, pertama tentang adanya kaitan antara perintah dan kehendak. Mu'tazilah berpendapat bahwa ada hubungan antara perintah dan kehendak Tuhan. Tuhan tidak akan memerintah sesuatu kecuali apabila Tuhan menghendakinya, dan tidak akan melarang sesuatu kecuali apabila Tuhan tidak menghendakinya. Tuhan tidak menghendaki maksiat. Oleh karena itu, Tuhan tidak memerintahkannya. Dalam hal ini Ibn Taimiyah berpendapat bahwa tidak ada hubungan antara perintah dan kehendak. Tuhan menghendaki ketaatan, maka Dia memerintahkannya. Tuhan tidak menghendaki maksiat, maka Dia melarangnya. Kehendak Tuhan terhadap maksiat adalah kehendak sebab-sebab maksiat. Kedua, Ibn Taimiyah berbeda dengan Mu'tazilah dalam hal rida, cinta, dan kehendak. Bagi Ibn Taimiyah kehendak itu bisa terjadi pada sesuatu yang bertentangan dengan perintah dan larangan Tuhan. Tuhan tidak senang dan rida terhadap perbuatan maksiat, namun Tuhan menghendakinya. Di sini Ibn Taimiyah mirip dengan Asy'ariyah, namun berbeda, menurut Asy'ariyah Tuhan menghendaki maksiat, namun Tuhan tidak rida dan tidak senang dengannya, bahkan murka, benci, dan melarangnya. Asy'ariyah membedakan antara kehendak dan kecintaan Tuhan. ${ }^{46}$

Ini adalah ciri khas Salafiyah, berlawanan dengan kepercayaan umum, menunjukkan benar-benar ketiadaan prasangka dan keterbukaan sikap terhadap semua pendapat dan terusmenerus membuat pernyataan-pernyataan yang bernada kebenaran tidaklah menjadi milik satu golongan saja, tetapi terbagi di antara semua golongan.

Dalam hal tujuan perbuatan Tuhan, Salafiyah menerima pendapat Maturidiyah, yaitu Tuhan menciptakan makhluk, menyuruh dengan perintah-perintah, dan melarang dengan larangan-larangan sesuai dengan hikmah kebijaksanaan-Nya. Kehendak Tuhan tidak berubah dikarenakan adanya hikmah. Hikmah bukanlah suatu keharusan bagi Tuhan, karena hikmah sesuai dengan sifat Tuhan Yang Maha Bijaksana. Hikmah merupakan keterangan akan kesempurnaan ciptaan, perintah, dan larangan Tuhan, bukan keharusan Tuhan. Tuhan menciptakan segala sesuatu bukanlah karena suatu tujuan atau dorongan, karena yang demikian itu akan mempersempit kehendak Tuhan. Tuhan adalah pencipta segala sesuatu dan di atas segala sesuatu. Tuhan tidak meminta pertanggungjawaban tentang sesuatu yang diperbuat-Nya, namun manusialah yang akan diminta Tuhan untuk mempertanggungjawabkan terhadap perbuatan yang dilakukannya. Manusia tidak dapat mengkiaskan Tuhan dengan sesuatu yang baik dan buruk yang dimilikinya, juga mewajibkan bagi Tuhan sesuatu sebagaimana mewajibkannya kepada manusia. Manusia menamakan yang demikian itu adalah keadilan dan kebijaksanaan Tuhan dengan segala kekurangan akal manusia dalam memahami hikmah Tuhan. Manusia tersebut adalah tidak mengerti bahwa Tuhan Maha Kuasa atas segala sesuatu dan apa yang dikehendaki mesti terjadi dan apa yang tidak dikehendaki mesti tidka terjadi. ${ }^{47}$

Sesungguhnya kekuasaan manusia dan kekuasaan Tuhan bukanlah saling bersaing secara eksklusif satu sama lainnya dalam menentukan dan menghasilkan tindakan manusia. Apa yang mungkin bagi Tuhan tidaklah sama dengan apa yang mungkin bagi manusia, karena Tuhan adalah yang menciptakan manusia. Misalnya Tuhan Maha Pengampun, mengapa Tuhan menciptakan neraka, padahal setiap manusia berpotensi untuk memohon ampun dan mendapatkan ampunan, di mana letak keadilan Tuhan dengan menciptakan neraka, sedangkan manusia mempunyai 
potensi untuk memohon ampunan? Inilah, salah satu bukti bahwa keadilan Tuhan dan keadilan manusia berbeda, karena esensi Tuhan dan esensi manusia berbeda.

\section{PENUTUP}

Dalam sejarahnya, gerakan Salafiyah telah memiliki banyak bentuk dan pengungkapan yang berbeda-beda sesuai kondisi yang berubah-ubah, sejak masa Ahmad ibn Hanbal sampai masa reformis yang dipelopori Jamaluddin al-Afghani (1839-1897 M) dan Muhammad Abduh (18491905 M). Namun, sepanjang fase-fasenya yang berbeda itu, pada intinya Salafiyah tetap merupakan gerakan reformasi dan perubahan yang berfokus pada masalah keyakinan, kemurnian Islam, pemulihan model Islam masa lalu, dan doktrinal yang tetap menekankan kebutuhan untuk kembali kepada Islam murni, seperti yang dilakukan generasi salaf. Agar ajaran Islam tidak dipertahankan sebagaimana adanya di dalam masyarakat, akan tetapi harus diwujudkan bagaimana seharusnya seperti yang dikehendaki al-Qur'an dan Hadis. Generasi salaf selalu menjadikan akal berada di belakang Qur'an dan Hadis. Akal hanya mampu membenarkan, mentaati, dan menerangkan pendekatan antara dalil akal (kontekstual) dengan dalil al-Qur'an dan Hadis (tekstual). Akal berkedudukan sebagai saksi bukan hakim, sebagi penetap bukan penentang, sebagai penjelas dari dalil yang terkandung dalam Qur'an dan Hadis.

Adapun pemikiran Salafiyah tentang takdir adalah beriman kepada : takdir baik dan buruk, kesempurnaan kekuasaan dan kehendak Tuhan, dan Tuhan adalah pencipta manusia dan menciptakan apa saja yang dimiliki manusia. Di samping itu, manusia juga mempunyai kebebasan berbuat apa saja yang diingininya dengan kekuatan dan kehendak manusia itu sendiri. Tuhan pencipta segala sesuatu, pencipta perbuatan manusia, namun manusia mempunyai kehendak untuk memilih perbuatan yang akan dilakukannya.

Dalam sejarah perkembangan pemikiran gerakan Salafiyah dan pemikiranya tentang takdir, ditemukan bahwa setiap kebenaran yang disampaikan manusia tidak menutup kemungkinan adanya kekurangan atau kelebihan dalam menyampaikan kebenarannya. Oleh karena itu, diperlukan pemikiran yang jernih dan terbuka dalam menyikapinya agar terhindar dari konflik, taklid buta, ta'assub mað̧ab, dan berhenti berpikir.

\section{Catatan Akhir}

1. Ahmad Warson Munawwir, Kamus al-Munawnir Arab-Indonesia Terlengkap, (Yogyakarta: Pondok Pesantren al-Munawwir Krapyak, 1984), h. 696

2. Abu Bakar Aceh, Salaf: Islam dalam Masa Murni, (Solo: Ramadhani, 1985), Cet. VI, h. 28

3. John L. Esposito, Dunia Islam Modern, (Bandung: Mizan, 2001), Jilid 5, h. 104

4. Abubakar Aceh, op. cit., h. 126

5. John L. Esposito, op. cit., h. 105

6. Harun Nasution, Teologi Islam : Aliran-aliran Sejarah Analisa Perbandingan, (Jakarta: UI Press, 1986), Cet. IV, h. 62-63

7. Ibid. h.63

8. Abubakar Aceh, op. cit., h. 127

9. Kafrawi Ridwan (ed.), op. cit., h. 204

10. Abu Zahrah, Sejarah Aliran dalam Islam Bidang Politik dan Aqidah, diterjemahkan oleh shobahussurur dari Tarikh al-Madzahib al-Islamiyyah fi as-siyasiyah wa al-'aqaid. (Gontor: Pusat Studi Ilmu dan Amal, 1991). H. 214

11. Ibid., h. 215

12. Ibid

13. John L. Esposito, op. cit., h. 105

14. Ibid., h. 105-106

15. Ibid., h. 106

16. Ibid.

17. Ibid. 
18. Harun Nasution, Pengembangan dalam Islam: Sejarah Pemikiran dan Gerakan, (Jakarta: Bulan Bintang, 1975), h. 62

19. Ibid.,h. 63

20. John L. Esposito, op. cit., h. 106

21. Harun Nasution, op. cit., h. 64

22. John L. Esposito, op. cit.,h.106

23. Ibid., h. 106

24. Ibid., h. 10

25. Ibid., h. 107-108

26. Ibid., h. 107-108

27. Ibid., h. 107

28. Ibid.

29. Ibid.

30. Ibid.

31. A. Hanafi, Pengantar Theology Islam, (Jakarta: al-Husna Zikra, 2001), Cet. VII, h.128

32. Abdullah bin Abdul Muhsin at-Turki, Dasar-dasar Aqidab para Imam Salaf, diterjemahkan oleh Nabhani Idris, dari mujma' al-I'tiqad Aimmah as-Salaf, (Jakarta: Qalam, 1995), h. 166167

33. Sirojuddin Ali, Akidah Islam dalam Perspektif Sejarab: Sekitar Diskusi Abli Salaf, dalam Sekitar Usuluddin dan Pemikiran Islam, 1997, h. 6-8

34. Abdullah bin Abdul Muhsin at-Turki, op. cit., h. 162-163

35. Ibid., h. 164-165

36. Ibid., h. 175-178

37. Ibid., h. 105

38. Abdullah bin Abdul Muhsin at-Turki, op. cit., h. 158

39. Abubakar Aceh, op. cit., h. 54

40. Ibid., h. 92

41. John L. Esposito, op. cit., h. 105

42. Ibid., h. 107

43. Abu Zahrah, Sejarah Aliran-aliran dalam Islam Bidang Politik dan Akidah, diterjemahkan oleh Shobahussurur dari Tarikh al-Madzahib al-Islamiyah fi as-Siyasiyah wa al-Aqaid, (Ponorogo: Pusat Studi Ilmu dan Amal, 1990), h. 226-227

44. Ibid.

45. Fazlur Rahman, Islam, diterjemahkan oleh Ahsin Muhammad dari Islam, (Bandung Pustaka, 2000), cet, IV, h. 161-162

46. Abu Zahra, op. cit., h. 227

47. Ibid., h. $227-228$

48. Ibid., h. 229-230

\section{REFERENSI}

Abdul Muhsin at-Turki, Dasar-dasar Aqidah Para Imam Salaf, terjemahan oleh Nabhani Idris, Jakarta : Qalam, 1995

Abu Zahrah, Muhammad. Tarikh al-Madzahib al-Islamiyyah, Kairo : Dar al-Fikr al-'Arabi, t.t.

Aceh, Abubakar, Salaf: Islam dalam Masa Murni, Solo: Ramadhan, 1985

Ali, Sirojuddin, Akidah Islam dalam Perspektif Sejarah dalam Jurnal Sekitar Ushuluddin dan pemikiran Islam, tahun 1997

Esposito, John 1, Dunia Islam Modern, Bandung : Mizan, Jilid 5, 2001

Hanafi, A, Pengantar Teologi Islam, Jakarta : al-Husna Zikra, Cet. VII, 2001 
Hootsma, M. Th., et al., The First Encyclopaedia of Islam 1913-1936, Leiden :E.J.Brill., 1987 Ibn Taimiyyah, Majmu' Fatawa, Beirut : Dar al-'Arabiyyah, $1398 \mathrm{H}$

Rasail Syaikh al-Islam Ibn Taimiyyah, Mesir : As-Sunnah al-Muhammadiyah, t.t.

Munawwir, Ahmad Warson, Kamus al-Munawwir Arab-Indonesia Terlengkap, Jogyakarta : P.P. Al-Munawwir Krapyak, 1984

Muslim, Sabih Muslim, al-Qahirah : Dar al-Hadits, 1991

Nasution, Harun, teologi Islam Aliran-aliran Sejarah Analisa Perbandingan, Jakarta : UI Press, 1986, Cetakan IV

....................Falsafat dan Mistisme dalam Islam, Jakarta : Bulan Bintang, 1973

\section{Bintang 1975}

Pembaharuan Dalam Islam: Sejarah Pemikiran dan Gerakan, Jakarta : Bulan

Rahman, Fazlur, Islam, diterjemahkan Ahsin Muhammad, Bandung: Pustaka, Cet. IV, 2000

Sharif, M.M., edit, History of Muslim Philosophy, Germany : otto Harrassowitz Wiesbaden, 1996

Subhi, Ahmad Mahmud, Fi Tlm al-Kalam, al-Iskandariyyah : Daral-Kutub al-Jami'iyyah, 1969

Sou'yb, Yoesoef, Sejarah Daulat Abbasiah III, Jakarta Bulan Bintang 1978. 